\title{
TRADITIONAL WHITE BRINED CHEESE AS A DELIVERY VEHICLE FOR PROBIOTIC BACTERIUM LACTOBACILLUS CASEI
}

\author{
Margita Dabevska-Kostoska ${ }^{1}$, Elena Velickova ${ }^{2}$, Slobodanka Kuzmanova ${ }^{2}$, \\ Eleonora Winkelhausen ${ }^{2 *}$ \\ ${ }^{1}$ Public Health Institution - Center for Public Health, Tetovo, Republic of Macedonia \\ ${ }^{2}$ Department of Food Technology and Biotechnology, Faculty of Technology and Metallurgy, \\ Ss. Cyril and Methodius University, Rudjer Bosković 16, 1000 Skopje, \\ Republic of Macedonia \\ winkelh@ukim.edu.mk
}

The traditional white brined cow cheese was tested as a delivery vehicle for probiotic bacteria. The cheese was manufactured from pasteurized cow's milk at an industrial scale, at the same time in three batches, each of 1000 liters milk. Two different initial concentrations of the probiotic bacterium Lactobacillus casei $\left(3.86 \cdot 10^{7}\right.$ and $\left.5.81 \cdot 10^{7} \mathrm{cfu} \mathrm{g}^{-1}\right)$ were used. The cheese had relatively short period of ripening (40 days), large percentage of fat ( $52 \%$ d.m.) and suitable $\mathrm{pH}$ values $(\sim 4.5)$ for the survival of probiotics. At the end of the ripening, the probiotic counts were $1.74 \cdot 10^{8}$ and $3.72 \cdot 10^{8} \mathrm{cfu} \mathrm{g}^{-1}$, respectively. There was no significant difference in most of the quality parameters at the $\mathrm{p}<0.05$ level between the two probiotic cheeses. Nitrogen fractions and fat content were the key components influencing the overall quality of the cheese samples. The principal component analysis of the sensory attributes demonstrated that the flavor contributed the most to the overall acceptance of all types of cheeses.

Keywords: white brined cheese; probiotic, Lactobacillus casei; sensory analysis

\section{ТРАДИЦИОНАЛНО БЕЛО САЛАМУРЕНО СИРЕЊЕ КАКО НОСАЧ НА ПРОБИОТСКАТА БАКТЕРИЈА LACTOBACILLUS CASEI}

\begin{abstract}
Традиционалното бело кравјо саламурено сирење беше испитано како носач на пробиотска бактерија. Сирењето од пастеризирано кравјо млеко беше произведено во индустриски услови, истовремено во три шаржи, секоја од по 1000 литри млеко. Беа употребени две различни почетни концентрации на пробиотската бактерија Lactobacillus casei $\left(3,86 \cdot 10^{7}\right.$ и $\left.5,81 \cdot 10^{7} \mathrm{cfu} \mathrm{g}^{-1}\right)$. Сирењето имаше релативно кус период на зреење (40 дена), голем процент маснотии ( $52 \%$ с.м.) и погодна pH вредност ( 4.5) што е добар предуслов за преживување на пробиотикот. На крајот на зреењето, пробиотикот беше присутен со $1,74 \cdot 10^{8}$ и $3,72 \cdot 10^{8} \mathrm{cfu} \mathrm{g}^{-1}$, соодветно. Меѓу повеќето квалитативни параметри на двете пробиотски сирења немаше статистички значајна разлика за ниво на $\mathrm{p}<0.05$. Азотните фракции и содржината на маснотии беа клучни параметри за севкупниот квалитет на сите сирења. Компонентната анализа на сензорските својства покажа дека аромата е таа што најмногу придонесува за севкупната прифатливост на сите видови сирења.
\end{abstract}

Клучни зборови: бело саламурено сирење; пробиотик; Lactobacillus casei; сензорска анализа 


\section{INTRODUCTION}

White brined cheese, both from sheep and cow's milk, is a well-known traditional dairy product in Balkan countries. For centuries it has been produced from raw milk on sheepfolds and farms. Today, the cheese is produced in factories from milk collected from a number of farmers. Following the current demands for food safety, it is no longer produced from raw milk; milk is pasteurized before use in cheese production. While consumers nowadays ask for traditional food products, they also strive for a larger assortment, more nutritive and safer foods and probiotic foods are products that fulfill these requirements. The Food and Agricultural Organization of the United Nations and the World Health Organization [1] define probiotics as "live microorganisms (bacteria and yeasts), which when digested or locally applied in sufficient numbers confer one or more specified demonstrated health benefits for the host".

A number of studies have demonstrated that specific probiotic cultures stimulate the growth of preferred microorganisms, crowd out potentially harmful bacteria by competing for attachment of the intestinal wall, promote host defense by stimulating systemic cell-mediated immunity (TH1) and have beneficial effects in patients with rotavirus and HIV-associated diarrhea [2-8]. Some probiotic bacteria may lower cholesterol level, improve lactose tolerance, and possess anti-mutagenic and anti-carcinogenic activities [9-11], as well as the ability to remove aflatoxins in liquid media [1214]. Most recently, Serrano-Niño et al. [15] have demonstrated the ability of five probiotic strains belonging to the genera Lactobacillus (4) and Bifidobacterium (1) to bind aflatoxin M1 and to reduce its bioaccessibility in artificially contaminated skim milk.

The most important probiotic bacteria typically associated with the human gastrointestinal tract belong to the lactic acid bacteria from the genera Lactobacillus and Bifidobacterium. These bacteria are Gram positive, rod-shaped, non-spore forming, catalase-negative organisms. Upon digestion, a sufficient number of probiotics must survive gastric and duodenal transit to be able to reach the large bowel. Although the number of probiotic bacteria that delivery foods must be able to support to provide a health benefit has not been firmly established, researchers suggest it should be between $10^{7}$ and $10^{9} \mathrm{cfu} \mathrm{g}^{-1}$ [16-18]. Using similar concentrations, Pitino et al. [19] tested six probiotic Lactobacillus rhamnosus strains for their ability to survive in the human upper gastrointestinal tract.
All tested strains showed good survival rate during both gastric and duodenal digestion.

Currently, probiotic cultures are successfully incorporated into large number of fermented milk products, especially in yogurts, ice creams $[18,20$ $26]$ and cheddar cheese [18, 27-31], but scarcely in white brined cheese [32-36]. In recent years, the consumption of cheese has increased rapidly. Cheese is a nutritious and ready-to-eat food that may possess certain advantages as a carrier of probiotic microorganisms, having a higher $\mathrm{pH}$ than yogurts and other fermented milk products. Furthermore, the texture of the cheese and its relatively high fat content are very suitable for protecting probiotic bacteria during all stages of their passing through the gastrointestinal tract $[31,37,38]$. The objective of this study was to enrich the traditional Macedonian product, white brined cow cheese, with the probiotic bacterium Lactobacillus casei, to monitor its survival and examine its impact on cheese composition during ripening, as well as on the overall sensory quality of the final cheese product.

\section{EXPERIMENTAL}

\subsection{Cheese manufacture}

The white brined cheese was manufactured from pasteurized cow's milk at an industrial scale at the local cheese making company. The milk was pasteurized at $73{ }^{\circ} \mathrm{C}$ for $15 \mathrm{~s}$, chilled to $14{ }^{\circ} \mathrm{C}$ and heated again to $39^{\circ} \mathrm{C}$. Three batches, each of 1000 liters milk were processed at the same time. A lyophilized mixed culture of Streptococcus thermophilus and Lactobacillus delbrueckii subsp. bulgaricus (Chr. Hansen Inc., Hørsholm, Denmark) was used as a starter culture. It was dispersed in the milk according to the instructions of the producer and the established practice in the cheese manufacturing company. After that, in two of the batches, $200 \mathrm{~g}$ and $300 \mathrm{~g}$ of lyophilized probiotic culture of Lactobacillus paracasei subsp. paracasei (L. casei) (Chr. Hansen Inc., Hørsholm, Denmark) were directly added and mixed to achieve initial cell concentrations of $3.86 \cdot 10^{7}$ and $5.81 \cdot 10^{7} \mathrm{cfu} \mathrm{g}^{-1}$, respectively. After 20 minutes, $200 \mathrm{ml}$ of chymosin (CHY-MAX Liquid Plus, Chr. Hansen Inc., Hørsholm, Denmark) were added to each batch and the milk was allowed to coagulate for $25 \mathrm{~min}$. The curd formed was cut $(2 \times 1.5 \mathrm{~cm})$ and allowed to heal for $10-15 \mathrm{~min}$. The cheese curd was stirred (5-10 min) and healed for $15 \mathrm{~min}$ at about $35^{\circ} \mathrm{C}$. This procedure was repeated three times. The curd was separated from the whey at $\mathrm{pH}$ 6.45 and molded. The molds were first pressed with $1 \mathrm{~kg}$ per $1 \mathrm{~kg}$ cheese during $1.75 \mathrm{~h}$, and then 
again with $2 \mathrm{~kg}$ per $1 \mathrm{~kg}$ cheese. The $\mathrm{pH}$ of the cheese samples varied from 5.40 to 5.62. The cheese was cut in smaller pieces and stored at $16{ }^{\circ} \mathrm{C}$ for $16 \mathrm{~h}$. The cheese was brined in $20 \%$ salt solution for $3 \mathrm{~h}$ at $\mathrm{pH}$ 4.6. The young cheese was then transferred into $5 \%$ salt solution and ripened for 20 days at $16^{\circ} \mathrm{C}$, and for the next 20 days at $4{ }^{\circ} \mathrm{C}$.

Cheese without probiotic bacterium was used as a control sample.

\subsection{Chemical analysis}

The physicochemical composition of milk was analyzed by ultrasonic milk analyzer whereas the antimicrobial residues were detected by the Chopin milk test.

Cheese samples were analyzed during the ripening period for moisture by drying at $105{ }^{\circ} \mathrm{C}$ using moisture analyzer Sartorius MA-40, salt was determined by the Morh method using $\mathrm{AgNO}_{3}$, titratable acidity (TA) by the AOAC method 920.124, fat by Van Gulick method (ISO 3433), and total nitrogen (TN) by the HACH-8075 Kjeldahl method. The $\mathrm{pH}$ of cheese was measured with a Mettler Toledo $120 \mathrm{pH}$-meter. The nitrogen fractions water-soluble nitrogen (WSN), 12\% trichloroacetic acid-soluble nitrogen (TCA) and $5 \%$ phosphotungstic acid-soluble nitrogen (PTA) were determined as described by Hayaloglu [39].

\subsection{Microbiological analysis}

Bacteriological analysis was performed according to ISO 21528-1:2004 for Enterobacteriaceae, ISO 6888-1/2:1999 for coagulase positive Staphylococci, ISO 4833 for aerobic mesophilic bacteria and ISO 16649-1/2:2001 for E. coli [40]. The population of the probiotic bacterium Lactobacillus casei was determined by plating sample dilutions on MRS agar and counting plate colonies after $48 \mathrm{~h}$ of incubation at $37^{\circ} \mathrm{C}$, as described by Bergamini et al. [37].

\subsection{Sensory analysis}

The sensory quality of the cheese was evaluated as previously described by DabevskaKostovska et al. [33]. Forty-seven panelists, whose ages ranged from 23 to 70 , were briefed prior to evaluation on the use of the sensory assessment techniques. Color and appearance, texture, aroma, and flavor, and overall acceptance of the cheeses were scored on a scale from 1 to 9 points. Higher scores meant more expressed attribute. All assessments were made at room temperature of about $22{ }^{\circ} \mathrm{C}$, relative humidity of 50 to $60 \%$, and identical illumination of the room. The panelists were given representative cheese samples, each weighing about $15 \mathrm{~g}$, placed on a disposable white plastic plate and coded with random numbers. To neutralize the taste, they used a glass of water.

\subsection{Statistical analysis}

Descriptive statistics and one-way analysis of variance (ANOVA) were performed on the experimental data to evaluate significant differences between the samples at $95 \%$ confidence interval according to Tukey's test using Minitab 15 statistical software. The Principal Component Analysis (PCA) was used to interpret the data collected during the sensory evaluation of the cheeses. All results represent mean values of 3 observations.

\section{RESULTS AND DISCUSSION}

\subsection{Quality of milk and white brined cheese}

The quality of thermally treated cow's milk used for the manufacture of white brined cheese is presented in Table 1. The physicochemical and bacteriological parameters of the milk are in compliance with the requirements of the Rulebook on the chemical composition of pasteurized milk [41] and the Rulebook on the microbiological safety of foods [40].

Table 1

The quality of thermally treated cow's milk used for manufacture of white brined cheeses

\begin{tabular}{lc|lc}
\hline \hline Physicochemical parameter & & Microbiological parameter & $3.33 \pm 0.579$ \\
\hline Total solids (\%) & $12.94 \pm 0.220$ & Enterobacteriaceae $\left(\mathrm{cfu} \mathrm{ml}^{-1}\right)$ & Not detected \\
Fat $(\%)$ & $4.53 \pm 0.082$ & Coagulase-positive Staphylococci $\left(\mathrm{cfu} \mathrm{ml}^{-1}\right)$ & $8.67 \cdot 10^{4} \pm 0.577 \cdot 10^{4}$ \\
Lactose $(\%)$ & $4.42 \pm 0.078$ & Aerobic mesophilic bacteria $\left(\mathrm{cfu} \mathrm{m}^{-1}\right)$ & \\
Protein $(\%)$ & $3.29 \pm 0.055$ & & \\
$\mathrm{pH}$ & $6.50 \pm 0.001$ & \\
Density $\left(\mathrm{g} \mathrm{ml}^{-1}\right)$ & $1.029 \pm 0.0047$ & \\
Electrolytic conductivity $\left(\mathrm{mS} \mathrm{cm}^{-1}\right)$ & $5.96 \pm 0.116$ & \\
Antibiotic residues & No positive test & \\
& detection & \\
\hline \hline
\end{tabular}


Table 2

Chemical composition of the traditional white brined cheese and cheese enriched with probiotic bacterium during ripening

\begin{tabular}{|c|c|c|c|c|c|c|c|c|c|}
\hline $\begin{array}{l}\text { Time } \\
\text { (day) }\end{array}$ & $\begin{array}{c}\text { Moisture } \\
(\%)\end{array}$ & phH-values & $\begin{array}{c}\text { Titratable acidity } \\
(\%)\end{array}$ & $\begin{array}{c}\mathrm{NaCl} \\
(\%)\end{array}$ & $\begin{array}{c}\text { Fats } \\
(\% \text { d.m. })\end{array}$ & $\begin{array}{c}\text { WSN/TN } \\
(\%)\end{array}$ & $\begin{array}{c}\text { TCA/TN } \\
(\%)\end{array}$ & $\begin{array}{c}\text { PTA/TN } \\
(\%)\end{array}$ & $\begin{array}{l}\mathrm{TN} \\
(\%)\end{array}$ \\
\hline \multicolumn{10}{|c|}{ Control sample (traditional cheese) } \\
\hline 3 & $53.29 \pm 0.115^{\mathrm{aA}}$ & $5.15 \pm 0.002^{\mathrm{aA}}$ & $0.97 \pm 0.010^{\mathrm{aA}}$ & $2.55 \pm 0.012^{\mathrm{aA}}$ & $42.86 \pm 0.054^{\mathrm{aA}}$ & $6.10 \pm 0.110^{\mathrm{aA}}$ & $2.20 \pm 0.153^{\mathrm{aA}}$ & $0.64 \pm 0.015^{\mathrm{aA}}$ & $2.70 \pm 0.020^{\mathrm{aA}}$ \\
\hline 10 & $54.99 \pm 0.655^{\mathrm{bA}}$ & $5.03 \pm 0.011^{\mathrm{aA}}$ & $1.15 \pm 0.010^{\mathrm{bA}}$ & $4.06 \pm 0.010^{\mathrm{bA}}$ & $50.00 \pm 0.001^{\mathrm{bA}}$ & $10.81 \pm 0.230^{\mathrm{bA}}$ & $3.97 \pm 0.023^{\mathrm{bA}}$ & $0.71 \pm 0.020^{\mathrm{aA}}$ & $2.48 \pm 0.053^{\mathrm{bcA}}$ \\
\hline 20 & $57.00 \pm 0.420^{\mathrm{cA}}$ & $4.48 \pm 0.480^{\mathrm{abA}}$ & $1.17 \pm 0.010^{\mathrm{bA}}$ & $4.67 \pm 0.010^{\mathrm{cA}}$ & $49.09 \pm 0.006^{\mathrm{bA}}$ & $12.83 \pm 0.242^{\mathrm{cA}}$ & $5.34 \pm 0.294^{\mathrm{cA}}$ & $1.30 \pm 0.045^{\mathrm{bA}}$ & $2.35 \pm 0.035^{\mathrm{cA}}$ \\
\hline 30 & $57.09 \pm 0.457^{\mathrm{cA}}$ & $4.71 \pm 0.011^{\mathrm{aA}}$ & $1.34 \pm 0.001^{\mathrm{cA}}$ & $4.86 \pm 0.005^{\mathrm{cA}}$ & $51.38 \pm 0.020^{\mathrm{cA}}$ & $16.27 \pm 0.144^{\mathrm{dA}}$ & $7.60 \pm 0.095^{\mathrm{dA}}$ & $1.39 \pm 0.045^{\mathrm{bcA}}$ & $2.34 \pm 0.040^{\mathrm{cA}}$ \\
\hline 40 & $57.05 \pm 0.110^{\mathrm{cA}}$ & $4.65 \pm 0.001^{\mathrm{aA}}$ & $1.33 \pm 0.006^{\mathrm{cA}}$ & $5.14 \pm 0.002^{\mathrm{dA}}$ & $51.89 \pm 0.593^{\mathrm{cA}}$ & $16.33 \pm 0.115^{\mathrm{dA}}$ & $7.64 \pm 0.055^{\mathrm{dA}}$ & $1.32 \pm 0.017^{\mathrm{bA}}$ & $2.39 \pm 0.040^{\mathrm{cA}}$ \\
\hline \multicolumn{10}{|c|}{ Probiotic $1^{*}$} \\
\hline 3 & $51.08 \pm 0.833^{\mathrm{aB}}$ & $5.01 \pm 0.011^{\mathrm{aB}}$ & $1.20 \pm 0.001^{\mathrm{aB}}$ & $2.52 \pm 0.015^{\mathrm{aB}}$ & $45.57 \pm 0.526^{\mathrm{aB}}$ & $6.17 \pm 0.107^{\mathrm{aA}}$ & $2.47 \pm 0.001^{\mathrm{aB}}$ & $0.75 \pm 0.020^{\mathrm{aB}}$ & $2.64 \pm 0.081^{\mathrm{aA}}$ \\
\hline 10 & $50.10 \pm 0.409^{\mathrm{aB}}$ & $4.79 \pm 0.020^{\mathrm{bB}}$ & $1,29 \pm 0.006^{\mathrm{bB}}$ & $3.90 \pm 0.010^{\mathrm{bB}}$ & $49.02 \pm 0.505^{\mathrm{bA}}$ & $11.62 \pm 0.118^{\mathrm{bB}}$ & $5.90 \pm 0.045^{\mathrm{bB}}$ & $1.19 \pm 0.020^{\mathrm{bB}}$ & $2.52 \pm 0.001^{\mathrm{bA}}$ \\
\hline 20 & $50.13 \pm 0.804^{\mathrm{aB}}$ & $4.48 \pm 0.023^{\mathrm{cA}}$ & $1.40 \pm 0.020^{\mathrm{cB}}$ & $3.91 \pm 0.006^{\mathrm{bB}}$ & $53.01 \pm 0.505^{\mathrm{cB}}$ & $12.86 \pm 0.100^{\mathrm{cA}}$ & $6.44 \pm 0.125^{\mathrm{cB}}$ & $1.40 \pm 0.040^{\mathrm{cA}}$ & $2.76 \pm 0.001^{\mathrm{cB}}$ \\
\hline 30 & $49.83 \pm 0.271^{\mathrm{aB}}$ & $4.41 \pm 0.011^{\mathrm{dB}}$ & $1.55 \pm 0.020^{\mathrm{dB}}$ & $3.77 \pm 0.271^{\mathrm{bB}}$ & $52.70 \pm 1.010^{\mathrm{cA}}$ & $13.53 \pm 0.103^{\mathrm{dB}}$ & $8.01 \pm 0.041^{\mathrm{dA}}$ & $1.42 \pm 0.040^{\mathrm{cA}}$ & $2.79 \pm 0.020^{\mathrm{cB}}$ \\
\hline 40 & $50.16 \pm 0.200^{\mathrm{aB}}$ & $4.39 \pm 0.006^{\mathrm{dB}}$ & $1.65 \pm 0.001^{\mathrm{eB}}$ & $4.03 \pm 0.006^{\mathrm{bB}}$ & $52.34 \pm 0.502^{\mathrm{cA}}$ & $13.89 \pm 0.105^{\mathrm{eB}}$ & $9.15 \pm 0.089^{\mathrm{eA}}$ & $1.46 \pm 0.001^{\mathrm{cB}}$ & $2.80 \pm 0.035^{\mathrm{cB}}$ \\
\hline \multicolumn{10}{|c|}{ Probiotic 2** } \\
\hline 3 & $51.89 \pm 0.300^{\mathrm{aB}}$ & $4.99 \pm 0.021^{\mathrm{aB}}$ & $1.27 \pm 0.011^{\mathrm{aC}}$ & $2.52 \pm 0.015^{\mathrm{aB}}$ & $48.86 \pm 0.121^{\mathrm{aC}}$ & $5.63 \pm 0.058^{\mathrm{aB}}$ & $2.52 \pm 0.086^{\mathrm{aB}}$ & $0.65 \pm 0.040^{\mathrm{aAB}}$ & $2.79 \pm 0.006^{\mathrm{aAB}}$ \\
\hline 10 & $50.15 \pm 0.363^{\mathrm{bB}}$ & $4.74 \pm 0.010^{\mathrm{bC}}$ & $1.17 \pm 0.006^{\mathrm{bC}}$ & $3.90 \pm 0.010^{\mathrm{bB}}$ & $49.80 \pm 0.167^{\mathrm{abB}}$ & $10.18 \pm 0.012^{\mathrm{bC}}$ & $5.52 \pm 0.043^{\mathrm{bC}}$ & $1.19 \pm 0.011^{\mathrm{bB}}$ & $2.69 \pm 0.036^{\mathrm{bB}}$ \\
\hline 20 & $49.81 \pm 0.250^{\mathrm{bB}}$ & $4.58 \pm 0.011^{\mathrm{cA}}$ & $1.39 \pm 0.006^{\mathrm{cB}}$ & $3.94 \pm 0.055^{\mathrm{bB}}$ & $50.18 \pm 0.518^{\mathrm{bC}}$ & $11.28 \pm 0.108^{\mathrm{cB}}$ & $5.61 \pm 0.011^{\mathrm{bA}}$ & $1.36 \pm 0.029^{\mathrm{cA}}$ & $2.79 \pm 0.030^{\mathrm{aB}}$ \\
\hline 30 & $48.54 \pm 0.551^{\mathrm{cC}}$ & $4.47 \pm 0.030^{\mathrm{dC}}$ & $1.51 \pm 0.010^{\mathrm{dC}}$ & $3.79 \pm 0.270^{\mathrm{bB}}$ & $52.00 \pm 0.480^{\mathrm{cA}}$ & $13.93 \pm 0.058^{\mathrm{dC}}$ & $5.59 \pm 0.155^{\mathrm{bB}}$ & $1.33 \pm 0.085^{\mathrm{cA}}$ & $2.83 \pm 0.047^{\mathrm{aB}}$ \\
\hline 40 & $48.05 \pm 0.512^{\mathrm{cC}}$ & $4.41 \pm 0.011^{\mathrm{dB}}$ & $1.68 \pm 0.025^{\mathrm{eB}}$ & $4.02 \pm 0.020^{\mathrm{bB}}$ & $51.51 \pm 0480^{\mathrm{cA}}$ & $13.94 \pm 0.384^{\mathrm{dB}}$ & $6.81 \pm 0.110^{\mathrm{cB}}$ & $1.40 \pm 0.040^{\mathrm{cB}}$ & $2.91 \pm 0.041^{\mathrm{acC}}$ \\
\hline
\end{tabular}

* Probiotic 1 refers to cheese inoculated with L. casei to achieve initial count of $3.86 \cdot 10^{7} \mathrm{cfu} \mathrm{g}^{-1}$

**Probiotic 2 refers to cheese inoculated with $L$. case $i$ to achieve initial count of $5.81 \cdot 10^{7} \mathrm{cfu} \mathrm{g}^{-1}$

Mean values and standard deviation, $(n=3)$. Different small letters within a column indicate significant differences due to ripening time within the same sample $(p<0.05)$. Different capital letters within a column indicate significant differences among samples $(p<0.05)$ 
The chemical composition of cheese samples is presented in Table 2 . The table displays the mean values of moisture, $\mathrm{pH}$, titratable acidity, salt content, fats-in-dry matter, nitrogen fractions soluble in water, trichloroacetic and phosphotungstic acid and total nitrogen. Throughout the ripening period, changes in the moisture content of the control and probiotic 2 cheese samples were statistically significant. The moisture content of the probiotic 1 sample remained the same. The $\mathrm{pH}$ values of the samples decreased gradually during ripening. At the end of the ripening period, significantly lower $\mathrm{pH}$ values of the samples containing probiotic bacteria $(4.39 \pm$ 0.006 for the sample P1 and $4.41 \pm 0.011$ for the sample P2) compared to $\mathrm{pH}$ of the control sample $(4.65 \pm 0.001)$ were observed. The addition of the probiotic culture affected the titratable acidity of the cheese. The acidity gradually increased during maturation, reaching statistically higher values of $1.65 \pm 0.001 \%$ and $1.68 \pm 0.025 \%$ in samples $\mathrm{P} 1$ and P2 compared to $1.33 \pm 0.006 \%$ in the control sample. The salt penetration was fast during the first 20 days and then levelled off in both of the probiotic cheeses, reaching about $4 \%$ at the end of the ripening period. After 40 days, the control sample had the highest salt content of $5.14 \pm 0.002 \%$.

At the end of the ripening period, all three types of cheese had fat concentrations of more than $50 \%$ d.m., which classified them as hard full-fat cheeses. Variations in the fat concentration observed during maturation may result from the salt absorption and/or diffusion of some water-soluble components between brine and cheese mass [39].

Proteolysis in cheese, as one of the main biochemical processes responsible for cheese ripening, involves complex reactions leading to various nitrogen compounds. These compounds contribute to the unique characteristics of the cheese. To follow and better understand this process it is necessary to examine the nitrogen fractions formed during ripening [31]. The ratios of WSN and TCA to TN in all cheese samples increased significantly throughout the 40-day ripening period (Table 2). The WSN/TN ratio of all cheeses increased by about 2.5 -fold. At the end of maturation, the WSN/TN value of the control sample $(16.33 \pm 0.115 \%)$ was significantly higher compared to the corresponding values of both probiotic samples $(\mathrm{P} 1=13.89 \pm 0.105 \%$; $\mathrm{P} 2=$ $13.94 \pm 0.384 \%)$. The largest increase of the TCA/TN ratio of 3.7-fold was observed in probiotic 1 sample. This increase may be due to the activity of bacterial proteinase and peptidase from the added Lactobacillus casei [30]. The PTA levels of the probiotic samples did not differ significantly, but they showed significant differences compared to the control sample. The results of the increased levels of PTA fraction suggest that Lactobacillus casei has an active peptidolytic system. The PTA fraction is composed of very small peptides, amino acids, and smaller nitrogen compounds other than dibasic amino acids and ammonia, and therefore the fraction can be used as a quite good indicator of free amino acid content $[42,43]$. The total nitrogen content increased in the probiotic samples, but not in the control sample.

\subsection{Microbiology of the cheeses}

The probiotic bacterium L. casei was incorporated into the white brined cheese at initial concentrations of $3.86 \cdot 10^{7}$ and $5.81 \cdot 10^{7} \mathrm{cfu} \mathrm{g}^{-1}$. The count of the probiotic bacterium during the ripening of cheese is shown in Figure 1. In the first phase of the cheese manufacture process, corresponding to the separation of the whey from the curd ( $3^{\text {rd }}$ day), there was an approximately $1.4 \mathrm{log}$ reduction in the count of probiotic bacteria in both samples. In the next period, the culture adapted to the conditions and continuously grew, reaching a plateau after 30 days of ripening. The counts were about $1 \cdot 10^{8} \mathrm{cfu} \mathrm{g}^{-1}$ (probiotic 1) and $3.8 \cdot 10^{8} \mathrm{cfu} \mathrm{g}^{-1}$ (probiotic 2). The viability of $L$. casei remained almost constant over next 30 days. Durability and biological activity of $L$. case $i$ in all stages of ripening and storage of cheese was facilitated by the physicochemical properties of the cheese (Table 2 ). It has to be noted that the white brined cheese enabled the probiotic to maintain its critical concentration level of $10^{7} \mathrm{cfu} \mathrm{g}^{-1}$. Abadía-García et al. [44] incorporated L. casei, L. rhamnosus GG and a commercial mix of probiotics in cottage cheese. $L$. casei count was $10^{8} \mathrm{cfu} \mathrm{g}^{-1}$, while the other probiotic populations remained at levels of about $10^{6} \mathrm{cfu} \mathrm{g}^{-1}$ during 28 days of storage at $8^{\circ} \mathrm{C}$.

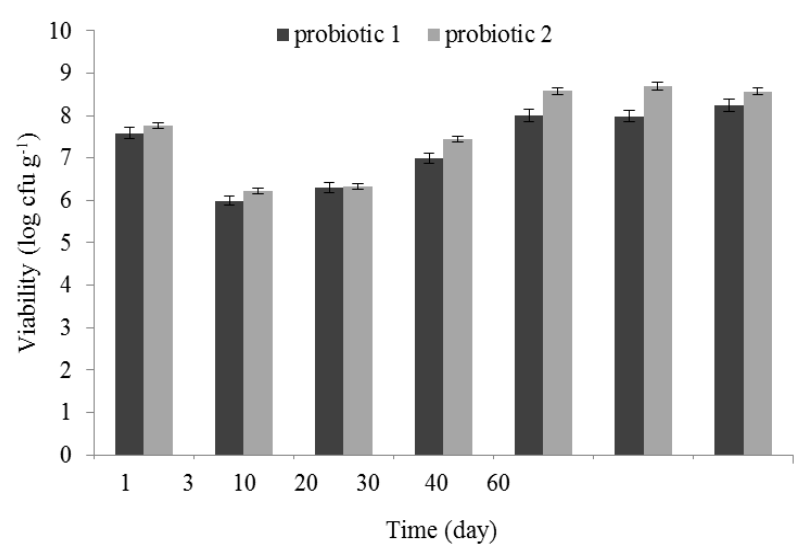

Fig. 1. Viability of Lactobacillus casei during ripening of the probiotic white brined cheese: probiotic 1 (initial L. casei count of $3.86 \cdot 10^{7} \mathrm{cfu}^{-1}$ ), and probiotic 2 (initial L. casei count of $5.81 \cdot 10^{7} \mathrm{cfu} \mathrm{g}^{-1}$ ) 
The cheese samples were also tested during the ripening period for the presence of Staphylococci and Escherichia coli. All samples were free of coagulase-positive Staphylococci, but not free from E. coli. However, it should be mentioned that all samples were in compliance with the microbiological safety requirements of cheese [40]. It was evident that the cell count in all samples decreased during ripening, and the probiotic cheeses had significantly lower counts than the control sample. At the $30^{\text {th }}$ and $40^{\text {th }}$ day of ripening, no E. coli cells were detected in the probiotic 2 sample. It can be hypothesized that the pathogenic bacterium was sensitive to organic acids and bactericides produced by the probiotic L. casei [45]. In cottage cheese containing probiotics, including $L$. casei, the population of the food-born pathogen $L$. monocytogenes was reduced by about one log cycle after 20 days of storage [44].

\subsection{Sensory analysis of the cheeses}

For the white cow cheese enriched with probiotic culture to be accepted by the consumers, it is not sufficient that the consumers know about the benefits of the probiotics; they have to be attracted by its sensorial properties as well. The results of the sensory analysis are presented in Figures 2 and 3. Although the average values of the quantified sensory attributes of the probiotic types of cheese were higher than those ascribed to the control sample, there was no statistically significant difference between them. The explanation lies in the high values of the relative standard deviation, which implies high differences among the panelists in perceiving the flavor, color and appearance, texture, and aroma of the cheeses, which is certainly connected to their individual diet habits. The fact that the panelists could not determine a significant difference between the samples could be advantageous for placing the probiotic cheese on the market. The consumers, used to the taste of traditional white brined cheese, could further enjoy this taste, and at the same time benefit from the presence of the probiotic bacteria.

It is well known that both the chemical composition and maturation process, including proteolysis, lipolysis and glycolysis of the cheese, have profound effects on its sensory properties. The $\mathrm{pH}$ of cheese has a major influence on the hydrolysis of triglycerides and consequent production of free fatty acids, thus affecting the development of the typical flavor and texture in cheese. Singh et al. [46] reported that at a $\mathrm{pH}$ of about 5, a considerable portion of the fatty acids are present as salts, and since they are non-volatile, they reduce the flavor sensation. The principal component analysis of the sensory attributes demonstrated that the acceptability of all three types of cheese was dependent primarily on their flavor (Fig. 3). Its aroma, color and physical appearance were of less importance.

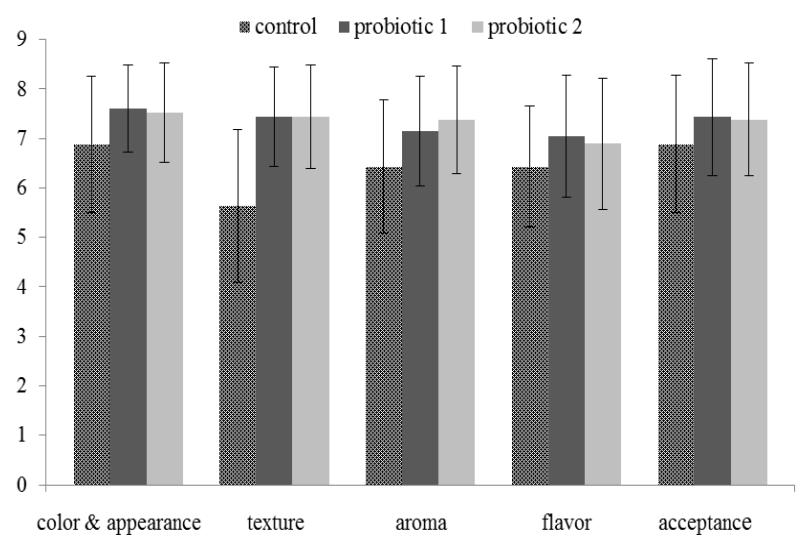

Fig. 2. Sensory characteristics of white brined cheese: control (no presence of $L$. casei), probiotic 1 (initial L. casei count of $3.86 \cdot 10^{7} \mathrm{cfu} \mathrm{g}^{-1}$ ), and probiotic 2 (initial L. casei count of $\left.5.81 \cdot 10^{7} \mathrm{cfu} \mathrm{g}^{-1}\right)$.

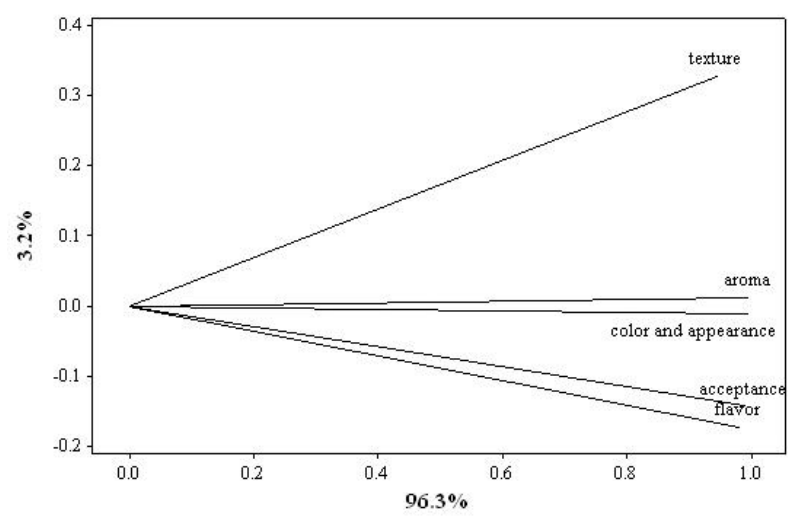

Fig. 3. Principal component analysis of the sensory attributes of the white brined cheese

In conclusion, the traditional white brined cow cheese showed to be a good delivery medium for probiotic culture Lactobacillus casei. It provided suitable conditions for survival of the bacterium at concentrations higher than the critical concentration of $10^{7} \mathrm{cfu} \mathrm{g}^{-1}$. Nitrogen fractions and fat content were the key components influencing the overall quality of the cheeses. The probiotic microorganism reduced the counts of the food-borne E. coli. The principal component analysis of the sensory properties showed that the acceptability of the probiotic cheeses depended mainly on their flavor. 
Acknowledgements. The authors are thankful to Stanislav Jovanović, the engineer at the milk factory in Tetovo, Macedonia, for his assistance in the manufacturing of the cheese, to Meri Ilieska, MSc, for providing and supporting the use of the probiotic cultures and to Milica Ristovska, MD, for the microbiological analysis.

\section{REFERENCES}

[1] FAO/WHO (Food and Agriculture Organization of the United Nations/World Health Organization). 2001. Health and nutritional properties of probiotics in food including powder milk with live lactic acid bacteria. A joint FAO and WHO expert consultation report. Accessed Feb. 2012. ftp://ftp.fao.org/docrep/fao/meeting/009/y6398e.pdf.

[2] S. Cunningham-Rundles, S. Ahrne, S. Bengmark, R. Johann-Liang, F. Marshall, L. Metakis, C., Califano, A. M. Dunn, C. Grassey, G. Hinds, J. Cervia, Probiotics and immune response. Am. J. Gastroenterol., 95, S22-S25 (2000).

[3] R. D. Rolfe, The role of probiotic cultures in the control of gastrointestinal health. J. Nutr., 130, 396S-402S (2000).

[4] M. L. Cross, Immunoregulation by probiotic lactobacilli: pro-Th1 signals and their relevance to human health, Clin. Appl. Immunol. Rev., 3, 115125 (2002).

[5] V. Rosenfeldt, K. F. Michaelsen, M. Jakobsen, C. N. Larsen, P. L. Moller, P. Pedersen, M. Tvede, H. Weyrehter, N. H. Valerius, A. Paerregaard, Effect of probiotic Lactobacillus strains in young children hospitalized with acute diarrhea. Pediatr. Infect. Dis. J., 21, 411-416 (2002).

[6] E. Isolauri, Probiotics for infectious diarrhoea, Gut, 52, 436-437(2003).

[7] T. Botić, T. D. Klingberg, H. Weingartl, A. Cencič, A novel eukaryotic cell culture model to study antiviral activity of potential probiotic bacteria, Int. J. Food Microbiol., 115, 227-234 (2007).

[8] D. Dimitrovski, A. Cencič, E. Winkelhausen, T. Langerholc, Lactobacillus plantarum extracellular metabolites: In vitro assessment of probiotic effects on normal and cancerogenic human cells. Int. Dairy J. 39, 293-300 (2014).

[9] K. Orrhage, E. Sillerstrom, J. A., Gustafsson, C. E. Nord, J. Rafter, Binding of mutagenic heterocyclic amines by intestinal and lactic acid bacteria, Mutat. Res.- Fund. Mol. M., 311, 239-248 (1994).

[10] K. Kailasapathy, J. Chin, Survival and therapeutic potential of probiotic organisms with reference to Lactobacillus acidophilus and Bifidobacterium spp., Immunol. Cell Biol., 78, 80-88 J. (2000).

[11] A. K. Anal, H. Singh, Recent advances in microencapsulation of probiotics for industrial applications and targeted delivery, Trends Food Sci. Tech., 18, 240-251 (2007).
[12] A. Hernandez-Mendoza, H. S., Garcia, J. L. Steele, Screening of Lactobacillus casei strains for their ability to bind Aflatoxin B1, Food Chem. Toxicol., 47, 1064-1068 (2009).

[13] B. Kabak, E. F. A. Brandon, I. Var, M. Blokland, A. J. A. M. Sips, Effects of probiotic bacteria on the bioaccessibility of aflatoxin B1 and ochratoxin A using an in vitro digestion model under fed conditions. J. Environ. Sci. Health, Part B, 44, 472-480 (2009).

[14] A. Hernandez-Mendoza, D. L. Guzman-de-Peña, A. F. Gonzalez, B. Vallejo, H. S. Garcia, In vivo assessment of the potential protective effect of Lactobacillus casei Shirota against aflatoxin B1, Dairy Sci. Techn., 9, 729-740 (2010).

[15] J. C. Serrano-Niño, A. Cavazos-Garduño, A. Hernandez-Mendoza, B. Applegate, M. G. Ferruzzi, M. F. San Martin-González, H. S. García, Assessment of probiotic strains ability to reduce the bioaccessibility of aflatoxin M1 in artificially contaminated milk using an in vitro digestive model. Food Control, 31, 202-207 (2013).

[16] A. Donnet-Hughes, F. Rochat, P., Serrant, J. M. Aeschlimann, E. J. Schiffrin, Modulation of nonspecific mechanisms of defence by lactic acid bacteria: effective dose. J. Dairy Sci., 82, 863-869 (1999).

[17] J. J. Rafter, Scientific basis of biomarkers and benefits of functional foods for reduction of disease risk: cancer, Brit. J. Nutr., 88, S219-S224 (2002).

[18] M. D. Sharp, D. J. McMahon, J. R. Broadbent, Comparative evaluation of yogurt and low-fat cheddar cheese as delivery media for probiotic Lactobacillus casei, J. Food Sci., 73, M375-M377 (2008).

[19] I. Pitino, C. L. Randazzo, G. Mandalarib, A. Lo Curto, R. M. Faulks, Y. Le Marc, C. Bisignano, C., Caggia, M. S. J. Wickham, Survival of Lactobacillus rhamnosus strains in the upper gastrointestinal tract. Food Microbiol., 27, 11211127 (2010).

[20] K. M. K. Kebary, S. A., Hussein, R. M. Badawi, Improving viability of bifidobacteria and their effect on frozen milk, Egyp. J. Dairy Sci., 26, 319337 (1998).

[21] K. Kailasapathy, Microencapsulation of probiotic bacteria: technology and potential applications. Curr. Iss. Intestinal Microb., 2, 39-48 (2002).

[22] A. B. Martin-Diana, C. Janer, C. Pelaez, T. Requena, Development of a fermented goat's milk containing probiotic bacteria. Int. Dairy J., 13, 827-833 (2003).

[23] C. Stanton, R. P. Ross, G. F. Fitzgerald, D. Van Sinderen, Fermented functional foods based on probiotics and their biogenic metabolites, Curr. Opin. Biotechnol., 16, 198-203 (2005). 
[24] E. R. Farnworth, I. Mainville, M. P. Desjardins, N. Gardner, I. Fliss, C. Champagne, Growth of probiotic bacteria and bifidobacteria in a soy yogurt formulation. Int. J. Food Microbiol., 116, 174-181 (2007).

[25] K. Kailasapathy, I. Harmstorf, M. Phillips, Survival of Lactobacillus acidophilus and Bifidobacterium animalis ssp. lactis in stirred fruit yogurts, LWT-Food Sci.Technol.-Leb., 41, 13171322 (2008).

[26] C. Senaka Ranadheera, C. A. Evans, M. C. Adams, S. K. Baines, Probiotic viability and physicochemical and sensory properties of plain and stirred fruit yogurts made from goat's milk, Food Chem., 135, 1411-1418 (2012).

[27] G. Gardiner, R. P. Ross, J. K. Collins, G. Fitzgerald, G. Stanton, Development of a probiotic cheddar cheese containing human-derived Lactobacillus paracasei strains. Appl. Environ. Microbiol., 64, 2192-2199 (1998).

[28] M. Playne, Researching, developing and commercializing probiotic cheese, Aust. Dairy Foods, Feb., 28-30 (2002).

[29] S. M. Phillip, K. Kailasapathy, L. Tran, Viability of commercial probiotic cultures (L. acidophilus, Bifidobacterium spp., L. casei, L. paracasei and L. rhamnosus) in cheddar cheese. Int. J. Food Microbiol., 108, 276-280 (2006).

[30] L. Ong, N. P. Shah, Influence of probiotic Lactobacillus acidophilus and L. helveticus on proteolysis, organic acid profiles, and ACEinhibitory activity of cheddar cheeses ripened at 4 , 8, and $12^{\circ}$ C, J. Food Sci., 73, M111-M120 (2008).

[31] H. K. Wang, C. Dong, Y. F. Chen, L. M. Cui, H. P. Zhang, A new probiotic cheddar cheese with high ACE-inhibitory activity and $\gamma$-aminobutyric acid content produced with koumiss-derived Lactobacillus casei Zhang, Food Technol. Biotech., 48, 62-70 (2010).

[32] M. Yilmaztekin, B. H. Özer, F. Atasoy, Survival of Lactobacillus acidophilus LA-5 and Bifidobacterium bifidum BB-02 in white brined cheese, Int. J. Food Sci. Nutr., 55, 53-60 (2004).

[33] M. Dabevska-Kostoska, S. Kuzmanova, E. Winkelhausen, A traditional brined white cheese enriched with probiotic bacteria Lactobacillus casei, Proceedings of the $1^{\text {st }}$ International Symposium on Traditional Foods from Adriatic to Caucasus, Tekirdağ, Turkey, 2010, pp. 213-215.

[34] P. Burns, F. Cuffia, M. Milesi, G. Vinderola, C. Meinardi, N., Sabbag, N. E. Hynes, Technological and probiotic role of adjunct cultures of non-starter lactobacilli in soft cheeses, Food Microbiol., 30, 45-50 (2012).
[35] M. Dabevska-Kostoska, E. Velickova, S. Kuzmanova, E. Winkelhausen, White brined cheese as a delivery medium for probiotic bacteria. Proceedings of the $6^{\text {th }}$ Central European Congress on Food -CEFood, Novi Sad, Serbia, 2012, pp. 1142-1147.

[36] R. Mahmoudi, H. Tajik, A. Ehsani, A. Farshid, P. Zare, M. Hadian, Effects of Mentha longifolia L. essential oil on viability and cellular ultrastructure of Lactobacillus casei during ripening of probiotic Feta cheese, Int. J. Dairy Technol., 66, 77-82 (2013).

[37] C. V. Bergamini, E. R. Hynes, A. Quiberoni, V. B. Suáres, C. A. Zalazar, Probiotic bacteria as adjunct starters: influence of the addition methodology on their survival in semi-hard Argentinean cheese, Food Res. Int., 38, 597-604 (2005).

[38] A. Gomes da Cruz, F. C. A. Buriti, C. H. Batista de Souza, J. A. Fonseca Faria, S. M. Isay Saad, Probiotic cheese: health benefits, technological and stability aspects. Trends Food Sci. Tech., 20, 344354 (2009).

[39] A. A. Hayaloglu, Comparison of different singlestrain starter cultures for their effects on ripening and grading of Beyaz cheese, Int. J. Food Sci. Tech., 42, 930-938 (2007).

[40] Rulebook on the microbiological safety of foods (2008). Official Gazette of the R. Macedonia Nr. 78.

[41] Rulebook on the chemical composition of pasteurized milk (2011). Official Gazette of the $R$. Macedonia Nr. 96.

[42] C. V. Bergamini, E. R. Hynes, C. A. Zalazar, Influence of probiotic bacteria on the proteolysis of a semi-hard cheese, Int. Dairy J., 18, 856-866 (2006).

[43] A. A. Hayaloglu, I. Karabulut, Primary and secondary proteolysis in eleven Turkish cheese varieties, Int. J. Food Prop. 16, 1663-1675 (2013).

[44] L. Abadía-García, A. Cardador, S. T. Martín del Campo, S. M. Arvízu, E. Castaño-Tostado, C. Regalado-González, B. García-Almendarez, S. L. Amaya-Llano, Influence of probiotic strains added to cottage cheese on generation of potentially antioxidant peptides, anti-listerial activity, and survival of probiotic microorganisms in stimulated gastrointestinal conditions, Int. Dairy J., 33, 184190 (2013).

[45] M. Millette, F. M. Luquet, M. Lacroix, In vitro growth control of selected pathogens by Lactobacillus acidophilus- and Lactobacillus casei-fermented milk. Lett. Appl. Microbiol., 44, 314-319 (2007).

[46] T. K. Singh, M. A. Drake, K. R. Cadwallader, Flavor of cheddar cheese: A chemical and sensory perspective, Compr. Rev. Food Sci. F., 2, 166-189 (2003). 